Document downloaded from:

http://hdl.handle.net/10251/66231

This paper must be cited as:

Hernández Crespo, C.; Oliver Rajadel, N.; Bixquert, J.; Gargallo Bellés, S.; Martín Monerris, M. (2015). Comparison of three plants in a surface flow constructed wetland treating eutrophic water in a Mediterranean climate. Hydrobiologia. 774(1):183-192. doi:10.1007/s10750-015-2493-9.

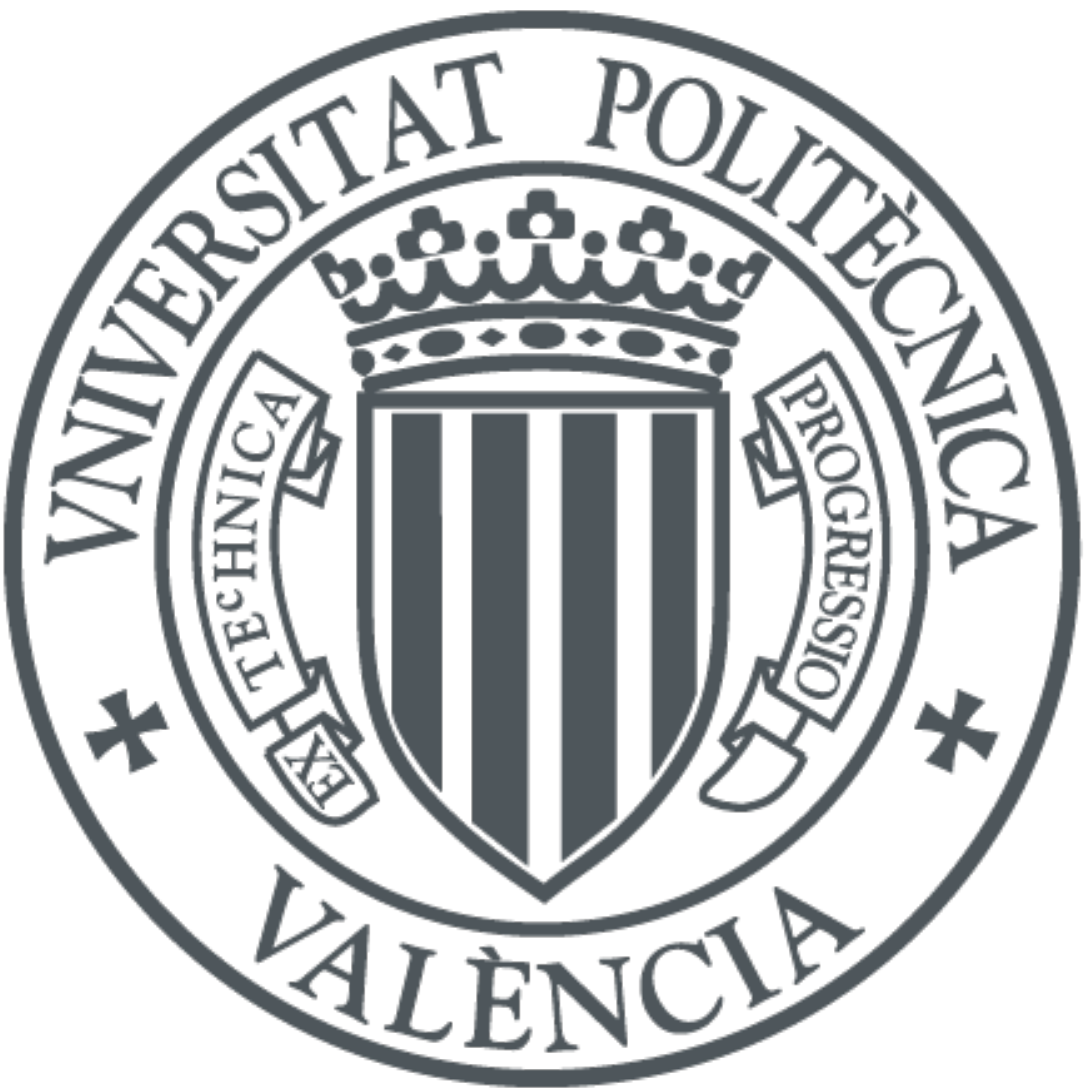

The final publication is available at

http://dx.doi.org/10.1007/s10750-015-2493-9

Copyright Springer Verlag (Germany)

Additional Information

The final publication is available at Springer via http://dx.doi.org/10.1007/s10750-015-2493-9 


\section{Comparison of three plants in a surface flow constructed wetland treating eutrophic water in a Mediterranean climate}

Carmen Hernández-Crespo 1,*

Email carhercr@upv.es

Nuria Oliver 1

Javier Bixquert 1

Sara Gargallo 1

Miguel Martín 1

1 Instituto de Investigación de Ingeniería del Agua y Medio Ambiente (IIAMA), Universitat Politècnica de València, Valencia, Spain

\section{Abstract}

The goal of this study is to examine the suitability of three plants, Typha spp., Phragmites spp. and Iris pseudacorus, in a free-water surface constructed wetland created to treat eutrophic water from Lake Albufera (Valencia, Spain), a wetland of international importance. The growth, coverage and nutrient content of the three plants were studied, and chemical analyses were performed according to standard methods. The maximum standing crops measured for each plant were 1.9, 18.2 and $3.3 \mathrm{~kg} \mathrm{~m}^{-2}$, respectively, and their average nutrient concentrations were 2.1, 1.2 and $1.7 \mathrm{~g} \mathrm{P} \mathrm{kg}^{-1}$ and $12.1,11.7$ and $10.1 \mathrm{~g} \mathrm{~N} \mathrm{~kg}^{-1}$, respectively. A multiple harvest of Iris pseudacorus revealed that the removal of nutrients could be increased up to $50 \%$ for $\mathrm{N}$ and $100 \%$ for P compared with a single harvest. Biomass decomposition assays showed high values for five-day biochemical oxygen demand (115-207 $\mathrm{mg}_{2} \mathrm{O}_{2} \mathrm{~g}^{-1}$, depending on the plant and its age) and a substantial release of phosphorus, up to $100 \%$ of that contained in the biomass, highlighting 
the need to remove the litter fall. This study provides key aspects for vegetation selection and management (planting and harvesting) in a novel application of constructed wetlands to enhance water quality and biodiversity.

\section{AQ1}

\section{Keywords}

Lake Albufera

Tancat de la Pipa

Constructed wetland

Eutrophic water

Plants

Multiple harvest

Guest editors: Pierluigi Viaroli, Marco Bartoli \& Jan Vymazal / Wetlands Biodiversity and Processes: Tools for Management and Conservation

\section{Introduction}

Over recent decades, free-water surface constructed wetlands (FWSCWs) have been widely used to treat domestic, industrial or agricultural wastewater and runoff (Vymazal, 2013). In a few cases, this technology is applied to treat eutrophic waters, but its use to restore lakes and rivers, as observed by Mitsch (1995), has increased over recent years (Coveney et al., 2002; Li et al., 2008; Dunne et al., 2012). This is the case for the Tancat de la Pipa constructed wetland (TPCW), which is aimed at treating eutrophic water, within the Albufera de Valencia (Spain) natural park (Martín et al., 2013). This project has multiple and interrelated objectives: to treat eutrophic water, to restore lost habitats in the natural park, to increase biodiversity from the bottom (zooplankton, macroinvertebrates) to the top (birds) of the food web, and to attain sustainable public use to disseminate the benefits of the project. Water quality is typically monitored and reported in these types of restoration projects, but other components of the ecosystem that are also enhanced are often neglected. However, it is important to obtain these data to demonstrate the environmental benefits provided by these projects. For example, Comín et al. (2001) demonstrated that wetland restoration could simultaneously improve water quality (using wetlands as filters for agricultural runoff), 
restore habitats for wetland birds and recover landscape heterogeneity. In the TPCW, different components of the ecosystem have been studied, revealing the benefits of the project for the improvement of water quality and biodiversity (water quality in Martín et al., 2013; phytoplankton and zooplankton in Rodrigo et al., 2013; wetland birds in Vera \& Giménez, $2013)$.

\section{AQ2}

In this paper, a comparative study of different plants in the TPCW is performed to test their different roles in constructed wetlands (CWs). In CWs designed to treat eutrophic water, the main goal of vegetation is to reduce solar radiation, thus limiting phytoplankton growth and promoting its decomposition and sedimentation. Other important functions of vegetation in CWs are as follows: reduction of water current, mitigation of wind velocity, induction of sedimentation and prevention of sediment resuspension, active nutrient uptake and retention within the biomass, provision of surface for periphyton growth, and oxygen transport to sediment both during the active growth phase and through the death culms (Vymazal, 2011). The vegetation cover can also add aesthetic values contributing to the landscaper quality. A wide variety of plants are used in FWSCWs, and often, several species are planted, creating mixed systems. Vymazal (2013) found up to 150 different species in a literature survey of 643 FWSCWs, with Typha spp. being the most common plant. Among the studies of FWSCWs treating eutrophic water, the following macrophytes were planted or were allowed to grow naturally: T. latifolia, Hydrocotyle ranunculoides, $P$. cordata, $S$. lancifolia, Alternanthera philoxeroides, Salix caroliniana and Ludwigia peruviana (Coveney et al., 2002), as well as Typha angustifolia (Li et al., 2008).

The use of subsurface flow CWs or floating systems to treat eutrophic water has also been reported by several authors (Sheng-Bing et al., 2007; Tang et al., 2009; Li et al., 2008, 2010). Li et al. (2008) compared the efficiencies of different types of CWs, including FWSCWs, horizontal subsurface flow CWs (HFCWs) and vertical subsurface flow CWs (VFCWs). They found that FWSCWs were less efficient at removing total nitrogen and total phosphorus. However, in addition to the reduction of nutrients, FWSCWs provide other environmental benefits, such as those previously mentioned. 
Several studies have addressed the capability of different plants to remove nutrients from treated water. The nutrient removal ability of plants is related to biomass density, growth speed and root distribution (Tanner, 1996; Cheng et al., 2009; Qiu et al., 2011). Qiu et al. (2011) found that a monoculture $\mathrm{CW}$ of species with faster growth rates and larger biomasses outperformed mixed wetlands, while the latter performed better than monocultures of slower growing species and presented more stable growth, root distribution and nutrient removal than monoculture wetlands. Fisher et al. (2009) also demonstrated a better performance of mixed wetlands, with the mixture of I. pseudacorus and other plants showing the best performance. Other advantages of mixed CWs are their lower susceptibility to seasonal changes and disturbances, as well as their more biodiverse microbial populations (Qiu et al., 2011; Zhang et al., 2010).

Our hypothesis is that the poly-culture of three different macrophyte, i.e. Typha spp. (cattail), Phragmites australis (common reed) and Iris pseudacorus (yellow iris), can perform better than monoculture for treating eutrophic waters.

\section{Materials and methods}

\section{Site description}

A detailed description of the Tancat de la Pipa constructed wetland (TPCW) can be found in Martín et al. (2013). Briefly, the TPCW is a former rice field (40 ha) converted into a reserve area in which 9 ha was used to create an FWSCW to treat eutrophic water from Lake Albufera (Valencia, Spain). The TPCW, which became operational in April 2009, consists of three sectors with seven cells that are $20 \mathrm{~cm}$ deep. Typical local plants of the natural park were selected. Four cells were originally planted with Typha spp. at a density of 1 stem $\mathrm{m}^{-2}$, which grew and developed appropriately, providing high coverage and shade to limit phytoplankton growth and promoting its removal; the other three cells were planted with Typha spp., Scirpus spp. and Cladium mariscus (Fig. 1). After the first growing season, Typha spp. was subjected to a strong herbivore predation that nearly caused its disappearance in some cells. Then, Phragmites spp. and Iris pseudacorus were planted to regain vegetation cover.

\section{Fig. 1}

Scheme of the TPCW and the timeline of plantings, harvestings and 
samplings. Sampling sites are squares in the scheme

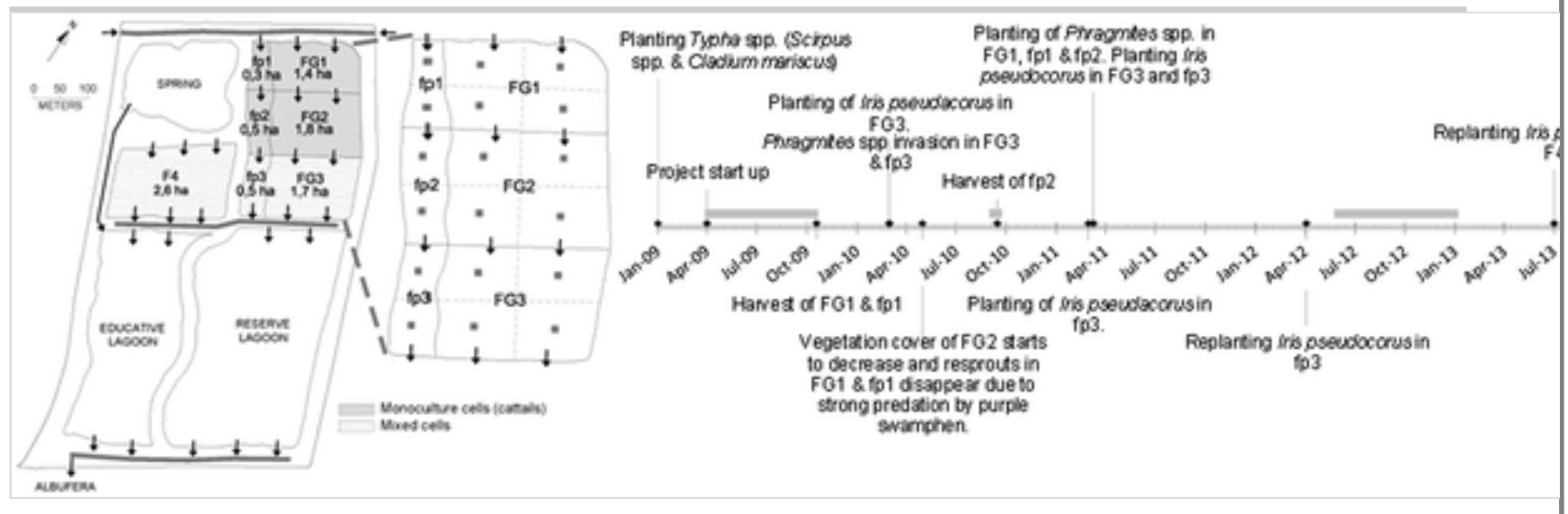

During the first two years of operation, the main sector of TPCW presented high removal rates of total nitrogen $(52 \%)$, total phosphorus $(65 \%)$, total suspended solids (75\%) and chlorophyll $a(46 \%)$; nitrogen (17\%) and phosphorus (19\%) were partially retained in plant biomass (Martín et al., 2013 ).

\section{Sampling and analytical determinations}

Samples of aboveground biomass were obtained in bounded surfaces $\left(0.25-1 \mathrm{~m}^{2}\right)$ in representative vegetated areas of the TPCW cells, after a visual inspection of the vegetation cover over all of the cells. All of the aboveground biomass was taken, including fresh and mature biomass (from previous years; detritus). The sampling periods were different because reed and yellow iris were planted later than cattails (Fig. 1). Cattails were sampled from Apr to Oct 2009, Sep 2010 and Jan 2013; reed and yellow iris were sampled in Jun 2012-Jan 2013 and in Nov 2014. In 2009, composite samples of cattails were collected in the four monocultured cells, as shown in Fig. 1, and four sampling campaigns were performed (to yield 17 samples). In 2010, a composite sample of cattails in the cell that still had vegetation cover (fp2) was obtained; the remaining cells no longer had an appreciable amount of cattails. Since 2010, reed and yellow iris have been planted each year, and the biomass that accumulated over different periods was collected, resulting in 11 samples of each plant. Samples were sediment-cleaned in situ, and the weight and length were measured. Once in the laboratory, representative subsamples were cut into small pieces, including all plant elements (leaves, stems, flowers), for moisture determination and ground for nutrient analysis. Analytical determinations were conducted according to official methods (MAPA, 
$1986)$ and were performed in duplicate for quality assurance. Dry weight (dw) was measured by drying the plant material at $65^{\circ} \mathrm{C}$ to a constant weight $(72 \mathrm{~h})$. Total nitrogen content was evaluated by a modified Kjeldahl method. For total phosphorus analysis, plant material was ashed at $450^{\circ} \mathrm{C}$ for $2 \mathrm{~h}$ and was subsequently extracted with $\mathrm{HCl}$ and measured photometrically (molybdenum blue). Ash content was measured by loss on ignition at $550^{\circ} \mathrm{C}$ for $2 \mathrm{~h}$. Vegetation cover was estimated as the area occupied by vegetation, considering the projection of the aboveground biomass on the ground.

To evaluate the potential oxygen demand derived from biomass decay, biochemical oxygen demand (BOD) assays were performed on some of the samples, including different ages and months of sampling (summer and autumn), to simulate the decomposition of biomass cut or placed on the ground by birds and litter. A mixture of ground biomass and filtered water from the outlet of TPCW $\left(0.6 \mathrm{~g}^{-1}\right)$ was used for BOD measurements using the OxiTop ${ }^{\circledR}$ (WTW) control system $\left(20^{\circ} \mathrm{C}\right)$. Data were adjusted to the first order model for organic matter degradation: $B O D_{t}=B O D_{u}(1-e$ $\left.{ }^{-k t}\right)$, where BODu is the ultimate BOD and $k$ is the rate constant. After 30 days of incubation, the nutrients in water were analysed to assess the net release of nutrients, associated to the decomposition of biomass.

\section{Statistical analyses}

Differences among the plant properties (moisture, ash and nutrient contents) were tested using one-way ANOVA analysis if normality was met (evaluated using the Shapiro-Wilk test) or using the Kruskal-Wallis test otherwise, with SPSS 15.0 (SPSS Inc., Chicago, Il, USA). In case of significant differences $(p<0.05)$, a post hoc analysis was performed for normal distributions using the Bonferroni or Tamhane tests, depending on whether homoscedasticity is met (evaluated using the Levene test), and by the Mann-Whitney U test for non-normal distributions. Correlation coefficients (Pearson) were calculated to study the relationships among the variables.

\section{Results}

\section{Biomass growth and nutrient removal}

The growth of aboveground biomass showed different patterns among the 
plants studied. The aboveground biomass of cattails and reed tends to increase over time, with a rapid rise in warmer months (from Jul to Oct) in the first and third year, respectively, until the maximum standing crop is reached (Fig. 2). Reed reaches its maximum standing crop after the fourth growing season (17.9 $\mathrm{kg} \mathrm{m}^{-2}$; rate constant $\left.0.007 \mathrm{day}^{-1}\right)$, and cattails appear to reach it from the second growing season $\left(1.9 \mathrm{~kg} \mathrm{~m}^{-2}\right.$; rate constant 0.028 day $^{-1}$ ). However, note that cattail information is only available beginning in until the second year because, afterwards, cattails nearly disappeared in the TPCW. The biomass data of reed and cattails can be suitably fitted to a logistic growth model using the equations displayed in Fig. 2. Yellow iris showed a different growth pattern, with certain data following a similar pattern to that above but with other data indicating a regression from the third year; indeed, some plants eventually disappeared after the fourth year. Therefore, two possible models could reproduce the behaviour of yellow iris, with some data that fit to a logistic model and other data indicating a behaviour similar to a depletion model.

\section{Fig. 2}

Evolution of aboveground biomass over time for Typha spp., Phragmites spp. and Iris pseudacorus. The $X$-axis is the time elapsed from the planting. Data are fitted to models of equations displayed in the graphics. The dotted line in the graphic of Phragmites spp. represents a sinusoidal function considering the seasonal behaviour of vegetation
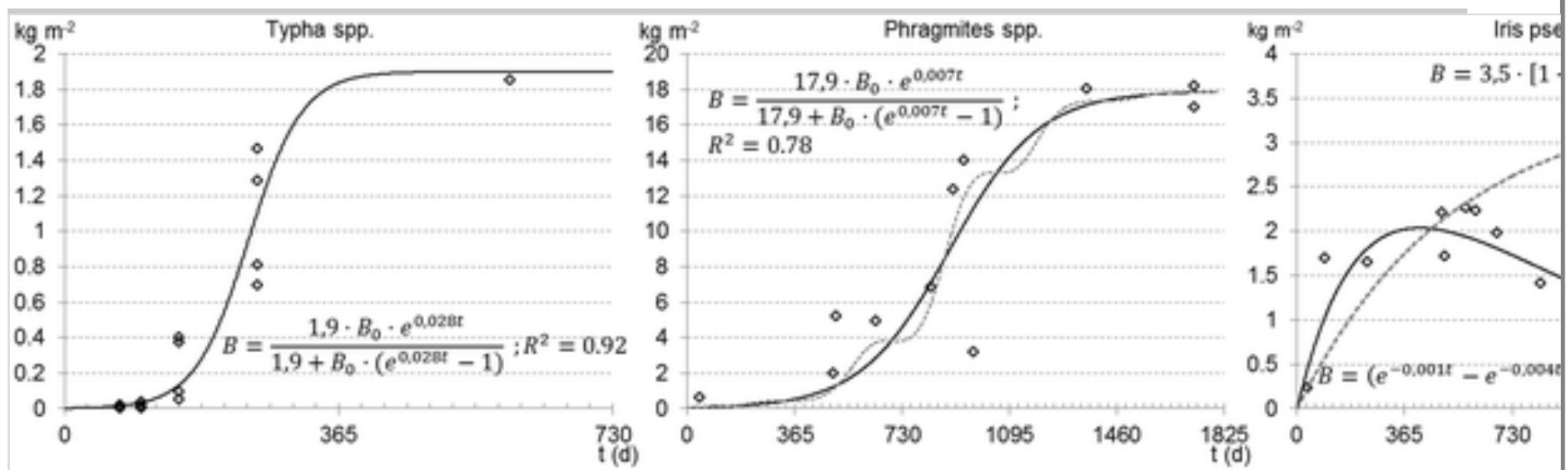

At the maximum standing crop time, the vegetation cover of areas occupied by cattails was $85 \%$, between 5 and $65 \%$ for areas with reed and between 35 and $65 \%$ for areas with yellow iris. The lowest coverage of reed was related to lower plant survival and a clumping habit. Applying the average percentage of vegetation cover to the standing stock, then the maximums would be $1.6 \mathrm{~kg} \mathrm{~m}^{-2}$ for cattails, $5.4 \mathrm{~kg} \mathrm{~m}^{-2}$ for reed and 
$1.8 \mathrm{~kg} \mathrm{~m}^{-2}$ for yellow iris.

On average, common reed has significantly less moisture (48\%) and ash content (5.7\%) than cattails (82 and 6.1\%, respectively) and yellow iris (72 and $10.0 \%$, respectively) (Fig. 3 ). Cattails presented a concentration of phosphorus $\left(2.1 \mathrm{~g} \mathrm{~kg}^{-1}\right)$ significantly greater than reed $\left(1.2 \mathrm{~g} \mathrm{~kg}^{-1}\right)$ $(p<0.05)$ though not much higher than yellow iris $\left(1.7 \mathrm{~g} \mathrm{~kg}^{-1}\right)(p>0.05)$. The concentration of total Kjeldahl nitrogen (TKN) did not notably differ among the three plants $\left(12.1,11.7\right.$ and $10.1 \mathrm{~g} \mathrm{~kg}^{-1}$, respectively) $(p>0.05)$. The wide variability of biomass characteristics is likely related to the plant age, as shown by the statistically significant correlation between age and the measured variables (Table 1).

\section{Fig. 3}

Moisture ( $\%$ total weight), ash content ( $\%$ dry weight) and nutrient concentrations $\left(\mathrm{g} \mathrm{kg}^{-1}\right)$ of the three plants studied (- represents the mean and circle represents the outliers)

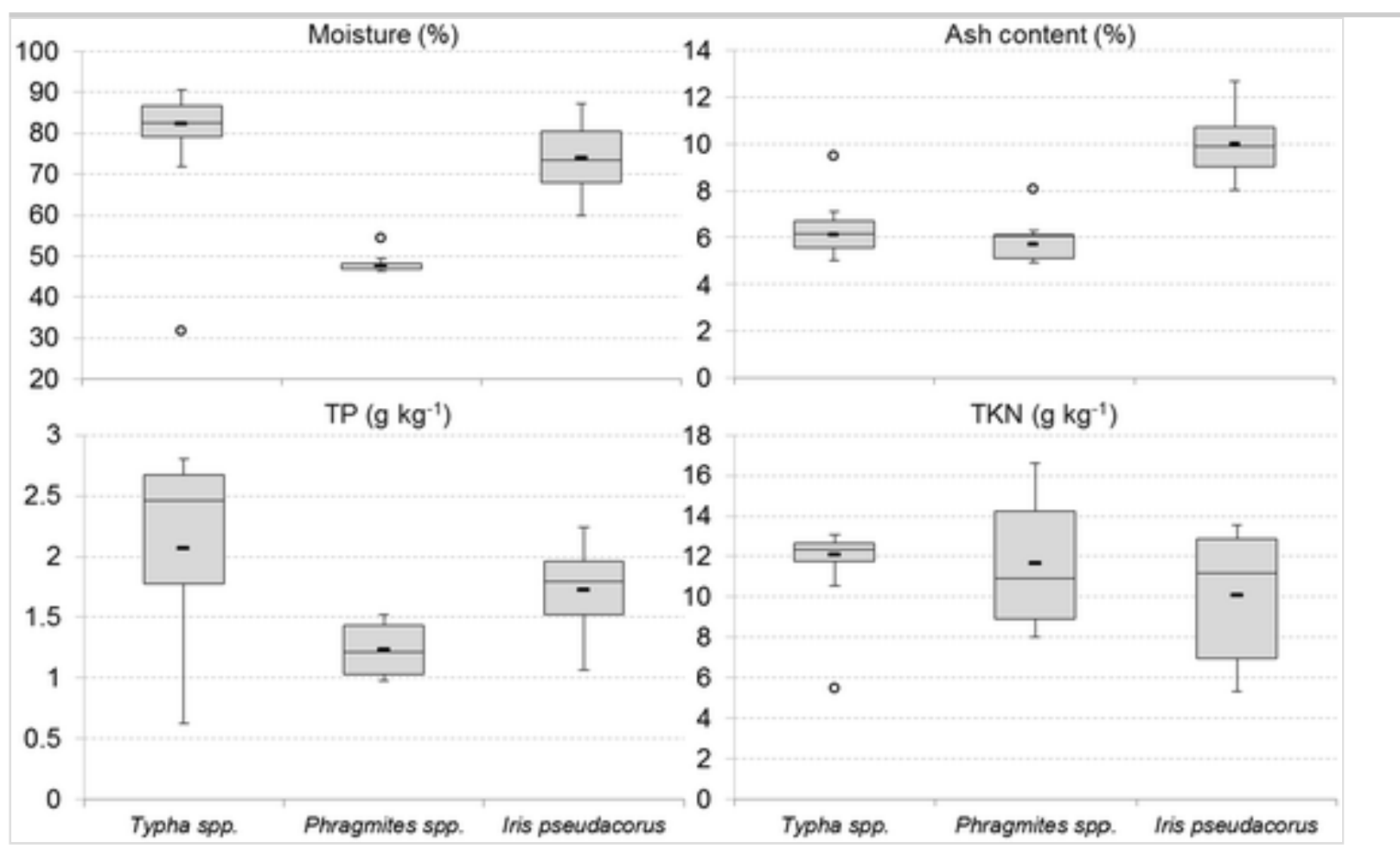

\section{Table 1}

Correlation coefficients between moisture and nutrient concentrations with the age of plants (time elapsed from planting)

\begin{tabular}{|l|l|l|l|}
\hline Plant & Moisture vs. age & TKN vs. age & TP vs. age \\
\hline Phragmites spp. & $-0.81^{* *}$ & -0.71 & $-0.84^{*}$ \\
\hline
\end{tabular}


Significance levels $* 0.05, * * 0.01$

The areal nutrient standing stock followed the standing crop evolution, attaining maximum values at the biomass peaks: $134.2 \mathrm{~g} \mathrm{~N} \mathrm{~m}^{-2}$ and $13.6 \mathrm{~g}$ $\mathrm{P} \mathrm{m}^{-2}$ for reed, $26.7 \mathrm{~g} \mathrm{~N} \mathrm{~m}^{-2}$ and $4.2 \mathrm{~g} \mathrm{P} \mathrm{m}^{-2}$ for yellow iris and $24.2 \mathrm{~g} \mathrm{~N}$ $\mathrm{m}^{-2}$ and $3.3 \mathrm{~g} \mathrm{P} \mathrm{m}^{-2}$ for cattails. These data correspond to vegetated areas. However, the vegetation cover was not homogeneous; therefore, the average nutrient standing stocks were much lower: $40.3 \mathrm{~g} \mathrm{~N} \mathrm{~m}^{-2}$ and $4.1 \mathrm{~g}$ $\mathrm{P} \mathrm{m}^{-2}$ for reed, $13.4 \mathrm{~g} \mathrm{~N} \mathrm{~m}^{-2}$ and $2.1 \mathrm{~g} \mathrm{P} \mathrm{m}^{-2}$ for yellow iris and $20.6 \mathrm{~g} \mathrm{~N}$ $\mathrm{m}^{-2}$ and $2.8 \mathrm{~g} \mathrm{P} \mathrm{m}^{-2}$ for cattails. The total nutrient load sequestered by aboveground biomass in the entire TPCW during 4 years of operation represents low percentages $(5 \% \mathrm{~N}, 8 \% \mathrm{P})$ of total inflow loads (44.5 tonnes of $\mathrm{N}, 3.5$ tonnes of $\mathrm{P}$ ). If this assessment is performed in each cell, the percentage sequestered by plants is considerably higher, approximately $30 \%$ for $\mathrm{N}$ and $\mathrm{P}$, in the last cells of the TPCW that receive lower loads than the first cells.

A multiple harvest assay performed with yellow iris showed an enhanced removal of nutrients because of the higher nutrient concentrations of the re-grown biomass. The repeated harvesting of the aboveground biomass induced an increase of nutrient concentrations in its tissues, from 7.1 to $21.8 \mathrm{~g} \mathrm{~N} \mathrm{~kg}^{-1}$ and from 1.7 to $4.0 \mathrm{~g} \mathrm{P} \mathrm{kg}^{-1}$ (Fig. 4).

\section{Fig. 4}

a Aboveground biomass re-grown after multiple harvesting. b Nutrient concentrations of re-grown biomass. $\mathbf{c}$ Nitrogen and $\mathbf{d}$ phosphorus standing stock to be removed without harvest and with multiple harvests 


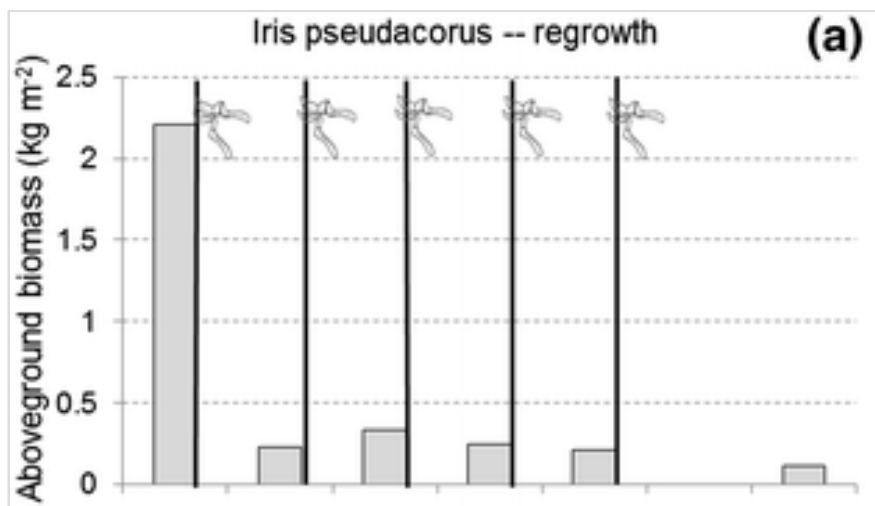

(b)
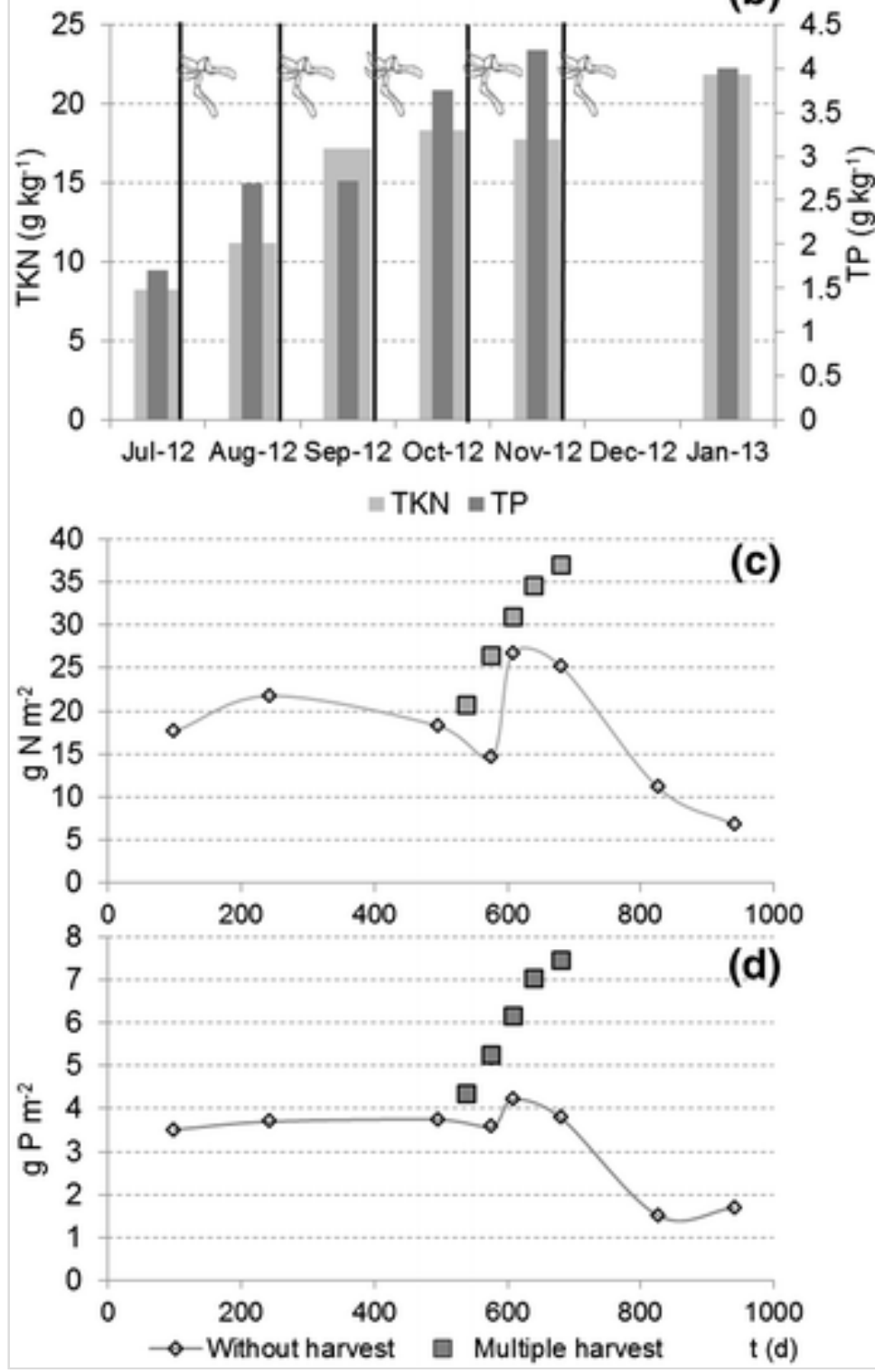

\section{Biomass decomposition and nutrient regeneration}

The data of BOD in the biomass decomposition assays were recorded every day for 30 days and were fitted to the first order model of organic matter decay. The oxygen consumption rates are reported in Table 2. BOD after 30 days was generally higher for reed, except for the sample corresponding to the second year. However, the BOD was exerted at a higher rate for the samples of yellow iris, possibly because iris has softer 
tissues than reed, with less lignin and cellulose (information from AINIA $^{1}$ ). For both macrophytes, the biodegradability decreases with age; likely, both accumulate refractory constituents with age.

\section{Table 2}

Biomass decomposition assays: $\mathrm{BOD}_{30}$ (biochemical oxygen demand after 30 days incubation); $k$ (rate constant of first order model); $\mathrm{PO}_{4}{ }^{3-}-\mathrm{P}$ and $\Sigma \mathrm{DIN}$ (sum of dissolved inorganic nitrogen: ammonia, nitrite, nitrate) are the nutrients regenerated in the assays, and the percentage of nutrient regenerated relative to nutrient concentration in biomass tissues is indicated

\begin{tabular}{|c|c|c|c|c|}
\hline & $\begin{array}{l}\mathrm{BOD}_{30} \\
\left(\mathrm{mg} \mathrm{g}_{\mathrm{AFDW}}{ }^{-1}\right)\end{array}$ & $k$ (day & $\begin{array}{l}\mathrm{PO}_{4}{ }^{3-}-\mathrm{P}(\mathrm{mg} \mathrm{g} \\
\left.{ }^{-1}\right) ; \%\end{array}$ & $\begin{array}{l}\sum \mathrm{DIN}\left(\mathrm{mg} \mathrm{g}^{-1}\right) ; \\
\%\end{array}$ \\
\hline $\begin{array}{l}\text { Phr. } \\
1 \text { year }\end{array}$ & 577 & 0.061 & $0.94 ; 62$ & $6.68 ; 25$ \\
\hline $\begin{array}{l}\text { Phr. } \\
2 \text { year }\end{array}$ & 449 & 0.038 & $1.17 ; 106$ & $1.17 ; 13$ \\
\hline $\begin{array}{l}\text { Phr. } \\
3 \text { year }\end{array}$ & 430 & 0.044 & $0.03 ; 3$ & $0.05 ;<1$ \\
\hline $\begin{array}{l}\text { Ir. } \\
1 \text { year }\end{array}$ & 493 & 0.088 & $1.44 ; 70$ & $0.03 ;<1$ \\
\hline $\begin{array}{l}\text { Ir. } \\
2 \text { year }\end{array}$ & 594 & 0.074 & $1.67 ; 89$ & $0.64 ; 5$ \\
\hline $\begin{array}{l}\text { Ir. } \\
3 \text { year }\end{array}$ & 381 & 0.060 & $1.43 ; 108$ & $0.87 ; 16$ \\
\hline
\end{tabular}

After the experiment, nutrients released from biomass decomposition were analysed. Results indicated that the plant biomass decay was accompanied by a significant regeneration of phosphorus, with percentages of net release higher than $60 \%$ of TP in tissues, in all but one sample. Conversely, the net release of dissolved inorganic nitrogen was considerably lower $(\Sigma \mathrm{DIN} \leq 25 \%)$.

\section{Discussion}

\section{Biomass growth and nutrient removal}

The experimental results showed the following growth rate: 
cattail $>$ reed $>$ iris (Fig. 2). Therefore, cattails reached their maximum earlier than the other two plants and provided high vegetation cover, approximately $100 \%$. However, after the first growing season, cattails were subjected to a strong herbivore predation by purple swamphen (Porphyrio porphyrio), nearly resulting in the disappearance of vegetation cover that did not recover after the first harvest (Oct-Nov 2009). The biomass decrease during the senescence period, which is typically observed in the growth of aboveground biomass (Wright and McDonnell, 1986; Comín et al., 2001; Vymazal \& Kröpfelová, 2005; Zhao et al., 2013), was registered in the present study for yellow iris in the 2 nd year, with a decrease from 2.26 (Sep) to $1.98 \mathrm{~kg} \mathrm{~m}^{-2}$ (Jan). For reed, the decrease was not documented because of the discontinuity in the vegetation sampling. To consider this seasonal biomass decrease, a sinusoidal function should be added to the equations (dotted line in Fig. 2-Phragmites), including environmental factors, such as temperature, solar radiation and nutrient availability (Wright and McDonnell, 1986; Asaeda et al., 2002).

Among the three studied macrophytes, reed attained the maximum areal standing crop, with the higher increases in the second and third year. However, this plant underwent a patchy growth and a low survival $(<20 \%)$. This clumpy habit has been recognised as a symptom of the reed dieback syndrome, commonly observed after prolonged submersion with eutrophic waters (Brix, 1999; Gigante et al., 2014). These issues did not affect the reed growth in the downstream cell of the system, where the water depth was generally lower $(0.08-0.20 \mathrm{~m})$ than in the upstream cells $(0.15-$ $0.25 \mathrm{~m}$ ) and reed properly expanded. After observing these difficulties, some cells of the TPCW were drained and dried several times during two months (Jul-Aug 2011, Mar-Apr 2012) to promote the growth and the spread of common reed. The drying process ensured the development of the surviving plants, which grew to the maximum values reported, but the expected spread was not achieved.

Meanwhile, yellow iris grew at a slower rate than reed or cattails, and its maximum standing crop was between their values. However, despite these apparent disadvantages, yellow iris grew at a slower but steady pace, providing good coverage. Additionally, it is not subject to bird predation and is aesthetically pleasing throughout the year, remaining green even in the coldest months. A weakness observed in the study was the regression of some plants from the third or fourth year (Fig. 2); some specimens of 
iris even disappeared after the fourth year.

Since each plant presents advantages and disadvantages, the mixed culture of the three macrophytes becomes suitable for providing a better TPCW performance (Fisher et al., 2009; Zhang et al., 2010). The common reed has to be planted in the shallower and less eutrophic cells, allowing the possibility to manage the submersion for optimising its growth and spreading. Cattails are preferably allocated in the deeper water, to contrast grazing. Yellow iris can be considered ubiquitary, thus providing complete vegetation coverage in all cells; iris can also add an aesthetic value due its phenology. The management, e.g. harvesting, of three different macrophytes has to be explored to evaluate its reliability and whether it can avoid the regression observed in aged plants.

The information obtained in this study is useful for designing polyphytic wetlands and performing their management. The best solution is to select plants with similar growth rates in order to avoid possible dominance and out competition (Qiu et al., 2011). The presence of grazers, e.g. waterfowl, is also a key issue; for example, in this study, cattails have been regulated by the purple swamphen which kept low the biomass density. It is interesting to continue planting cattails because of their role as food for their natural regulator and for other waterfowl species. Data of the growth rate, standing crop and nutrient standing stock are also necessary to predict the quantity and properties of biomass that will need to be managed after harvest operations. For example, aged reed and cattails could be properly managed by energy recovery treatment because they present lower moisture and ash content. A study on the thermal behaviour of cattail biomass showed that it could be used for energy recovery (Ciria et al., 2005 ). In the case of yellow iris, with higher humidity throughout the year, other management alternatives, such as anaerobic digestion (De Meester et al., 2012) or compost production, may be more appropriate.

Compared with values reported in the literature, the nutrient concentrations and maximum standing crop reached by cattails were close to those reported by Li et al. (2008) in an FWSCW for treating eutrophic water (approximately $2.2 \mathrm{~kg} \mathrm{~m}^{-2}, 15 \mathrm{~g} \mathrm{~N} \mathrm{~kg}^{-1}$ and $3 \mathrm{~g} \mathrm{P} \mathrm{kg}^{-1}$ ). For common reed and yellow iris, data of biomass in studies of $\mathrm{CWs}$ aimed at treating eutrophic water have not been found. A review of natural eutrophic wetlands has reported maximum aboveground biomass values between 2.4 
and $9.9 \mathrm{~kg} \mathrm{~m}^{-2}$ for Phragmites australis (Vymazal \& Kröpfelová, 2005), and the maximum value measured in this study $\left(5.4 \mathrm{~kg} \mathrm{~m}^{-2}\right)$ was within this range. Zhao et al. (2013) reported values of maximum aboveground biomass of approximately $2 \mathrm{~kg} \mathrm{~m}^{-2}$, finding higher biomass in the site less polluted within a eutrophicated lake in which the concentrations of nutrients in aboveground biomass were lower $\left(14.9 \mathrm{~g} \mathrm{~kg}^{-1}\right.$ and $2.0 \mathrm{~g} \mathrm{P} \mathrm{kg}$ $\left.{ }^{-1}\right)$ than in the site of poor water quality $\left(31.1 \mathrm{~g} \mathrm{~N} \mathrm{~kg}^{-1} ; 3.2 \mathrm{~g} \mathrm{P} \mathrm{kg}^{-1}\right)$. In the case of yellow iris, a value of $0.1 \mathrm{~kg} \mathrm{~m}^{-2}$ was found in an FWSCW treating wastewater (Arroyo et al., 2013), which is much lower than the maximum biomass measured in the present study; conversely, the concentration of nutrients was much higher in the cited study $(33.3 \mathrm{~g} \mathrm{~N} \mathrm{~kg}$ $\left.{ }^{-1} ; 6.9 \mathrm{~g} \mathrm{P} \mathrm{kg}^{-1}\right)$. Therefore, the concentrations of nutrients in tissues measured in TPCW are generally lower than those measured in other water bodies, but the aboveground biomass was higher. Thus, there appears to be an inverse correlation between nutrient concentration and aboveground biomass. Nutrient concentrations in the aboveground biomass also appear to be positively correlated with the concentration of nutrients in the treated water.

Regarding the nutrient standing stock, Brezinova \& Vymazal (2015) showed that it is necessary to discriminate among the different plant components (flowers, leaves and shoots) to accurately evaluate the actual nutrient standing stock. Thus, the values obtained in the present study can be considered an approximation to the actual nutrient standing stock; if more detailed information is required, for example, to make an accurate mass balance, it would be desirable to distinguish among these plant components. As stated in the results section, nutrients sequestered by plants represent a low percentage of inflow loads to the TPCW $(<10 \%)$. However, it is important to maintain a high vegetation cover to provide the shadow effect on the phytoplankton and to reduce the risk of sediment resuspension. In addition, the management of vegetation by harvesting and removing fallen leaves is important to remove nutrients and organic matter from the system.

Harvesting can potentially damage macrophytes before nutrient translocation (Maddison et al., 2009). However, we did not observe stress in iris stands after successive biomass harvests. Although, with a low frequency monitoring, we assumed nutrient translocation did not occur from July 2012 ( $\left.8.3 \mathrm{~g} \mathrm{~N} \mathrm{~kg}^{-1}, 1.7 \mathrm{~g} \mathrm{P} \mathrm{kg}^{-1}\right)$ to January $2013(12.8 \mathrm{~g} \mathrm{~N} \mathrm{~kg}$ 
${ }^{-1}, 1.9 \mathrm{~g} \mathrm{P} \mathrm{kg}^{-1}$ ). In parallel, the iris accumulated nutrients and remained green throughout the year.

The multiple biomass harvesting favours the nutrient removal, which is twofold greater than in unharvested stands for phosphorus and 1.5 times higher for nitrogen. This enhancement was similar to that found for other macrophytes (Suzuki et al., 1989), although a great variability can be found for different chemical elements (Vymazal et al., 2010). Based on our study, under the local climatic conditions, the best strategy is to harvest twice a year, in March and August, thereby avoiding a disturbance during the breeding season. Furthermore, we have evidenced that harvesting should be started the second year onwards, after the macrophyte stands have consolidated attaining a high density and the capacity to regrow quickly.

\section{Biomass decomposition and nutrient regeneration}

The decomposition rates of macrophyte biomass decrease with age and are greater for iris, due to softer tissues; than reed. The biodegradability depends in fact on the content of refractory components in the plant tissues (Longhi et al., 2008). The biomass decay is accompanied by a significant oxygen consumption and the regeneration of inorganic $\mathrm{P}$ and $\mathrm{N}$. This result highlights the need to periodically remove biomass from the system, either by harvesting or by removing fallen leaves (litter and, especially, fresh leaves) to maintain the concentrations of organic matter and dissolved oxygen at levels suitable for aquatic life and to avoid the accretion of sediment, which could lead to the silting of the CW (Álvarez \& Bécares, 2006). This removal is especially important for fresh leaves and shoots because they exert higher oxygen demand per mass unit.

Regarding the values obtained for rate constants and BOD, note that they represent maximum rates and oxygen demand because the assays were performed with ground material to promote the bacterial activity under aerobic and stable temperature conditions. Thus, the values of the decomposition rate constants obtained in this study are not directly comparable to those obtained by other authors who measured the values through loss of mass in litter-bag experiments performed in field, generally obtaining lower values for the rate constants $\left(0.004\right.$ day $^{-1}$ for P. australis by Menéndez et al., 2001; 0.005 day $^{-1}$ for Typha latifolia by Álvarez \& Bécares, 2006; $0.003 \mathrm{day}^{-1}$ for P. australis by Longhi et al., 2008). 
However, Xie et al. (2004) found higher decomposition rates in litter-bag experiments with floating and submerged macrophytes (0.009-0.099 day -1 , depending on nutrient availability). Nevertheless, the conclusion remains the same in that the process is slow but it is necessary to remove biomass from the system.

\section{Conclusions}

This study demonstrates that yellow iris is a suitable macrophyte for designing constructed wetlands aimed at managing and controlling eutrophic waters. Yellow iris can be used in mixed cultures with cattails and reed, which have different habits and can support biodiversity and biogeochemical processes in the wetland.

\section{AQ3}

This study also provides evidences of the suitability of biomass harvesting for controlling both the biomass growth and nutrient removal. Two harvests a year can greatly enhance nutrient removal. In the same time, harvesting and biomass removal prevent biomass accumulation within the systems, thus avoiding oxygen consumption and nutrient regeneration from decomposition processes.

\section{Acknowledgments}

The authors acknowledge the anonymous reviewers and the editor for their valuable comments to improve this paper.

Compliance with ethical standards

Ethical rules This manuscript has been prepared according to the ethical rules of Hydrobiologia, and it has not been submitted to other journals.

\section{References}

Álvarez, J. A. \& E. Bécares, 2006. Seasonal decomposition of Typha latifolia in a free-water surface constructed wetland. Ecological Engineering 28: 99-105.

Arroyo, P., I. Blanco, R. Cortijo, E. L. Calabuig \& G. Ansola, 2013. Twelve-Year performance of a constructed wetland for municipal wastewater treatment: water quality improvement, metal distribution in 
wastewater, sediments, and vegetation. Water, Air and Soil Pollution 224: 1762.

Asaeda, T., L. H. Nam, P. Hietz, N. Tanaka \& S. Karunaratnex, 2002. Seasonal fluctuations in live and dead biomass of Phragmites australis as described by a growth and decomposition model: implications of duration of aerobic conditions for litter mineralization and sedimentation. Aquatic Botany 73: 223-229.

Březinova, T. \& J. Vymazal, 2015. Nitrogen standing stock in Phragmites australis growing in constructed wetlands - Do we evaluate it correctly? Ecological Engineering 74: 286-289.

Brix, H., 1999. The European research project on reed die-back and progression (EUREED). Limnologica 29: 5-10.

Cheng, X. Y., W. Y. Chen, B. H. Gu, X. C. Liu, F. Chen, Z. H. Chen, X. Y. Zhou, Y. X. Li, H. Huang \& Y. J. Chen, 2009. Morphology, ecology, and contaminant removal efficiency of eight wetland plants with different root systems. Hydrobiologia 623: 77-85.

Ciria, M. P., M. L. Solano \& P. Soriano, 2005. Role of macrophyte Typha latifolia in a constructed wetland for wastewater treatment and assessment of its potential as a biomass fuel. Biosystems Engineering 92: 535-544.

Comín, F. A., J. A. Romero, O. Hernández \& M. Menéndez, 2001. Restoration of wetlands from abandoned rice fields for nutrient removal, and biological community and landscape diversity. Restoration Ecology 9: 201-208.

Coveney, M. F., D. L. Stites, E. F. Lowe, L. E. Battoe \& R. Conrow, 2002. Nutrient removal from eutrophic lake water by wetland filtration. Ecological Engineering 19: 141-159.

De Meester, S., J. Demeyer, F. Velghe, A. Peene, H. Van Langenhove $\&$ J. Dewulf, 2012. The environmental sustainability of anaerobic digestion as a biomass valorization technology. Bioresource Technology 121: 396-403. 
Dunne, E. J., M. F. Coveney, E. R. Marzolf, V. R. Hoge, R. Conrow, R. Naleway, E. F. Lowe \& L. E. Battoe, 2012. Efficacy of a large-scale constructed wetland to remove phosphorus and suspended solids from Lake Apopka, Florida. Ecological Engineering 42: 90-100.

Fisher, J., C. J. Stratford \& S. Buckton, 2009. Variation in nutrient removal in three wetland blocks in relation to vegetation composition, inflow nutrient concentration and hydraulic loading. Ecological Engineering 35: 1387-1394.

Gigante, D., C. Angiolini, F. Landucci, F. Maneli, B. Nisi, O. Vaselli, R. Venanzoni \& L. Lastrucci, 2014. New occurrence of reed bed decline in southern Europe: do permanent flooding and chemical parameters play a role? Comptes Rendus Biologies 337: 487-498.

Li, L., Y. Li, D. K. Biswas, Y. Nian \& G. Jiang, 2008. Potential of constructed wetlands in treating the eutrophic water: evidence from Taihu Lake of China. Bioresource Tecnology 99: 1656-1663.

Li, X. N., H. L. Song, W. Li, X. W. Lu \& O. Nishimura, 2010. An integrated ecological floating-bed employing plant, freshwater clam and biofilm carrier for purification of eutrophic water. Ecological Engineering 36: 382-390.

Longhi, D., M. Bartoli \& P. Viaroli, 2008. Decomposition of four macrophytes in wetland sediments: organic matter and nutrient decay and associated benthic processes. Aquatic Botany 89: 303-310.

Maddison, M., T. Mauring, K. Remm, M. Lesta \& Ü. Mander, 2009. Dynamics of Typha latifolia L. populations in treatment wetlands in Estonia. Ecological Engineering 35: 258-269.

Ministerio de Agricultura, Pesca y Alimentación (MAPA). 1986. Métodos oficiales de análisis, vol. 3. Mundi-Prensa, Madrid.

Martín, M., N. Oliver, C. Hernández-Crespo, S. Gargallo \& M. C. Regidor, 2013. The use of free water surface constructed wetland to treat the eutrophicated waters of lake L'Albufera de Valencia (Spain). Ecological Engineering 50: 52-61. 
Menéndez, M., M. Martínez, O. Hernández \& F. Comín, 2001. Comparison of leaf decomposition in two mediterranean rivers: a large eutrophic river and an oligotrophic stream (S Catalonia, NE Spain). International Review of Hydrobiology 86: 475-486.

Mitsch, W. J., 1995. Restoration of our lakes and rivers with wetlands an important application of ecological engineering. Water Science and Technology 31: 167-177.

Qiu, Z. C., M. Wang, W. L. Lai, F. H. He \& Z. H. Chen, 2011. Plant growth and nutrient removal in constructed monoculture and mixed wetlands related to stubble attributes. Hydrobiologia 661: 251-260.

Rodrigo, M. A., M. Martín, C. Rojo, S. Gargallo, M. Segura \& N. Oliver, 2013. The role of eutrophication reduction of two small manmade Mediterranean lagoons in the context of a broader remediation system: effects on water quality and plankton contribution. Ecological Engineering 61: 371-382.

Sheng-Bing, H., Y. Li, K. Hai-Nan, L. Zhi-Ming, W. De-Yi \& H. ZhanBo, 2007. Treatment efficiencies of constructed wetlands for eutrophic landscape river water. Pedosphere 17: 522-528.

Suzuki, T., N. Ariyawathie \& Y. Kurihara, 1989. Amplification of Total Dry Matter, Nitrogen and Phosphorus Removal from Stands of Phragmites Australis by Harvesting and Reharvesting Regenerated Shoots. In Hammer, D. A. (ed.), Constructed Wetlands for Wastewater Treatment. Lewis Publishers, Chelsea, MI: 530-535.

Tang, X., S. Huang, M. Scholz \& J. Li, 2009. Nutrient removal in pilotscale constructed wetlands treating eutrophic river water: assessment of plants, intermittent artificial aeration and polyhedron hollow polypropylene balls. Water Air Soil Pollution 197: 61-73.

Tanner, C. C., 1996. Plants for constructed wetland treatment systems a comparison of the growth and nutrient uptake of eight emergent species. Ecological Engineering 7: 59-83.

Vera, P. \& M. Giménez, 2013. Colonización y evolución inicial de la 
comunidad de paseriformes en un humedal restaurado del Este de la península ibérica. Revista de anillamiento 31-32: 61-72.

Vymazal, J., 2011. Plants used in constructed wetlands with horizontal subsurface flow: a review. Hydrobiologia 674: 133-156.

Vymazal, J., 2013. Emergent plants used in free water surface constructed wetlands: a review. Ecological Engineering 61: 582-592.

Vymazal, J. \& L. Kröpfelová, 2005. Growth of Phragmites australis and Phalaris arundinacea in constructed wetlands for wastewater treatment in the Czesch Republic. Ecological Engineering 25: 606-621.

Vymazal, J., L. Kröpfelová, J. Švehla \& J. Štíchová, 2010. Can multiple harvest of aboveground biomass enhance removal of trace elements in constructed wetlands receiving municipal swage? Ecological Engineering 36: 939-945.

Wright, R. M. \& J. A. McDonnell, 1986. Macrophyte growth in shallow streams: biomass model. Journal of Environmental Engineering 112: 967-982.

Xie, Y., D. Yu \& B. Ren, 2004. Effects of nitrogen and phosphorus availability on the decomposition of aquatic plants. Aquatic Botany 80: $29-37$.

Zhang, C. B., J. Wang, W. L. Liu, S. X. Zhu, H. L. Ge, S. X. Chang, J. Chang \& Y. Ge, 2010. Effects of plant diversity on microbial biomass and community metabolic profiles in a full-scale constructed wetland. Ecological Engineering 36: 62-68.

Zhao, Y., X. Xia \& Z. Yang, 2013. Growth and nutrient accumulation of Phragmites australis in relation to water level variation and nutrient loadings in a shallow lake. Journal of Environmental Sciences 25: 1625 .

${ }^{1}$ http://www.lifealbufera.org/index.php/es/networking. 